\title{
Trends in South American weapons purchases at the beginning of the new millennium
}

\author{
Tendências para as compras de armas na América do Sul \\ no início do novo milênio
}

RAFAEL DUARTE VILLA* JULIANA VIGGIANO**

Rev. Bras. Polít. Int. 55 (2): 28-47 [2012]

In recent years, with some frequency it is heard that Latin America, especially South America, is witnessing the rise of an arms race. Frequent reports in the press and strong statements made by politicians in the region have fueled this fear ${ }^{1}$. At the same time, scholars have also reached to this conclusion, as pointed out by Malamud and Garcia: "The famous arms race in Latin America, led by Venezuela, is no longer just talk." ${ }^{2}$

This paper is divided into three parts. At first, the paper offers a brief historic overview of military spending in Latin America, emphasizing South America's last decade. In the following section, the longest of them all, an analytical map of military spending on armaments in six South American countries (Venezuela, Chile, Colombia, Brazil, Peru and Argentina) is presented, giving special attention to what kind of weapons is being purchased, from whom they are being purchased, and which are the factors that motivate and allow such purchases. Finally, the paper seeks to identify trends for the second decade of the new millennium. Although this paper analyzes data referent to the first decade of the 2000s, particular attention is placed to the period 2003-2007, since it represents a turning point in arms purchases for South American countries.

\footnotetext{
* Associate professor of the University of Sao Paulo (USP) (rafaelduvi@gmail.com).

** PhD professor of the Federal University of Santa Catarina (UFSC).

1 In late 2006, the President of Costa Rica, Oscar Arias, in response to the purchase of weapons by countries like Venezuela and Chile, said that the region was entering in an arms race period. References to news on the subject can be found at: Downie, Andrew, Time World, "A South American Arms Race?", Friday, December 21, 2006. Available at <http://www.time.com/time/world/article/0,8599,1697776,00.html>, accessed August 23, 2011; The Economist, "South America defence: speak fraternally but carry a stick", May 29, 2008; Oppenheimer, "Just what Latin America needs - a new arms race", Miami Herald, September 17, 2007; p. 16A; Jorge Marirrodriga, "Latino américa se rearma" (Rearmament in Latin America), El Pais, April 29, 2006; Casto Ocando, "Planea Venezuela una compra récord de armamentos" (Does Venezuela plan a big purchase of arms?), El Nuevo Herald, September 16, 2006. April 2006.
}

2 Malamud, C. Encina Garcia, C. "Rearmament or renovation of military equipment in Latin America", Working Paper 31/2006, Real Instituto Elcano, available at <http://realinstitutoelcano.org/documentos/283. asp>, accessed August 25, 2009. 


\section{Introduction (setting the context)}

Military expenditures in Latin American countries (that is, countries geographically situated in both South and Central America) amount to US\$ 60.4 billion (in 2007 constant prices) in $2010^{3}$. From 2003 to 2007, expenditure of this nature increased at an annual rate of $6 \%$, a low amount if compared to other regions of the world. The analyzed data indicates a pattern of spending during the first decade of the millennium: In South America, military expenditure constantly grew while in Central America numbers remained virtually constant. The lowest spending year in South America (1999) accounted for 86\% of the region's expenditure; the highest-spending year (2007) accounted for $97 \%$. It is important to underline once again, however, that these figures are still quite low if compared to other so-called peripheral regions of the international system such as Asia and the Middle East, and are incomparable to the huge amount of resources allocated by "first world" regions like North America and Western Europe. In Latin America, South American countries are responsible for the largest increases in military spending during the 2003-2007 period, Venezuela (78.53\%), Chile (53\%), and Ecuador (49\%) being the main responsible countries. It is also in South America where are the countries with higher military budgets in the region: Brazil, which accounts for $46 \%$ of expenditures; Colombia, which accounts for 15\%; and Chile, with 13\%. ${ }^{4}$ South America alone accounts for US\$ 39.6 billion of the US\$ 44 billion invested in the military in 2007. What could explain such an increasing pattern during the mentioned years? The rise of military spending coincides with a series of three consecutive years of strong economic growth in South America (2004-2006, at an average rate of approximately 5.3\%), a phenomenon experienced last in the 1970s, when average rates were close to $7 \%$. Although growth had declined in 2007 to $4.9 \%$, some of the strongest economies, like Brazil, Argentina, Chile, and Venezuela, maintained their rates considerably high: $8.7 \%, 5.3 \%, 5.1 \%$, and $8.4 \%$, respectively ${ }^{6}$. On the other hand, the positive economic performance was also accompanied by an increase in macroeconomic indicators in almost all major countries in this sub-region:

3 See: SIPRI, "Military expenditure by region in constant US dollars, 1988-2010, available at <http://www. sipri.org/research/armaments/milex/resultoutput/worldreg2011/worldregtable11/view>, accessed December 22, 2011. This number can vary depending on the source, but in general the figures are not far apart.

4 For all these data, see: Stalenheim, C.; Perdomo, C. \& Skons, E. "Military Expenditure", in SIPRI Yearbook 2008. Armament, disarmament and international security. Oxford: Oxford University Press, 2008, p. 200.

5 For this information, see: Centro de Proyecciones Económicas da Comisión Económica para América Latina (CEPAL) (Center of Economic Projections of the Economic Commission for Latin America and the Caribbean), 2006.

6 Estado de São Paulo Online, "PIB da Argentina cresceu 8,7\% em 2007, diz Cristina Kirchner" (Argentina’s GDP grew 8.7\% in 2007, says Cristina Kirchner), December 2, 2008. Available at <http://www.estadao.com.br/ economia/not_eco122970,0.htm>, accessed August 27, 2011; Dinheirama, "Alta do PIB, a Selic e o crescimento do Brasil" (The rise of the GDP, the Selic rate and Brazilian growth), available at <http://dinheirama.com/ blog/2008/03/14/alta-do-pib-a-selic-e-o-crescimento-do-brasil/>, accessed August 27, 2011. 
inflation, fiscal adjustments, and public debt reduction, combined with high flows of foreign capital that had an impact on dollar devaluation policies.

Based on that, some experts have interpreted South America's interest in increasing military spending over the past five years as the result of high levels of economic growth, a stronger currency due to the devaluation of the dollar - which stimulates import practices -, and political will to modernize the armed forces of the sub-region, which have obsolete arms stockpile?.

Notwithstanding, is it enough to claim an arms race in South America based on the fact that there is an increase in investment numbers? Indeed, reactions coming from some countries may suggest a movement in that direction, raising concern about this possibility; for instance, Colombia concerns with Venezuela's arms purchases, particularly regarding uncertainty about the "ultimate consumers" of such products. Thus, the Colombian government has come to favor mechanisms for monitoring Venezuelan arms purchases ${ }^{8}$. Bolivia and Peru have also expressed concern with increasing on armaments spending by Chile. As points out a study by Gustavo Gutiérrez, "[...] military expenditure, measured in US dollars, in relation to the GDP shows [...] a great amount of spending by Chile in a program to modernize the Army, which effectively raises suspicion and alarms its neighbors [...]." This paper, however, does not intend to discuss whether or not there is an "arms race" in South America, but to systematize information that can substantiate such debate by mapping military expenditure in countries of the region that maintain Armed Forces with complex structures and that purchase sophisticated weaponry, drawing tendencies for this entering decade.

\section{An outlook of weapons' purchases in South America}

Since 2005, Chile and Venezuela (and, to a lesser extent, Brazil) had the greatest increase in weapons imports among South American countries, giving rise to the delicate question of whether their excessive concern with modernizing the armed forces could not have the negative effect of fueling an arms race in the region and destabilizing governments by transferring part of the acquired arsenal to national or regional non-state groups. The Venezuelan case has drawn the most attention.

7 The International Institute for Strategic Studies (IISS), "Caribbean and Latin America - Defence and economics”, in: Military Balance 2008, London: Routledge, 2008, p. 59.

8 See: Layla Ibrahim Abdallah Dawood. "Compra de rifles de assalto russos e o problema do tráfico de armamento de pequeno porte" (resenha) (Purchase of Russian assault rifles and the problem of trafficking in small arms" (book review), Conjuntura Internacional, PUC-Minas, available at <http://www.pucminas.br/conjuntura>, accessed September 15, 2011.

9 Gutiérrez, Carlos “Chile, Perú y Bolivia: entre el conflicto y la cooperación” (Chile, Peru and Bolivia: between conflict and cooperation), Sepúlveda, Isidro (ed.). Seguridad Humana y Nuevas políticas de defensa en Iberoamérica (New Human Security and defense policies in Latin America). Madrid: Instituto Universitario General Gutiérrez Mellado, Madrid, 2007. p. 308-9 (our translation). 
The Stockholm International Peace Research Institute (SIPRI) published in the summer of 2008 its annual balance report of export, import and transfer of weapons around the world accounting for numbers of the previous year. Interestingly, for the first time, SIPRI's report devoted a whole chapter to analyze the purchase and transfer of arms in South America. At SIPRI Yearbook 2008, emphasis is given to three countries: Brazil, Chile, and Venezuela. In a mediumterm analysis, SIPRI showed a percentage increase in arms transfers in South America: "States of South America accounted for 5\% of the volume of international transfers of conventional weapons imported for the period 2003-2007 - and 47\% higher than in 1998-2002." 10 These acquisitions could be transforming South America in an "emerging arms market." For example, in the cases of Chile and Venezuela, the volume of conventional weapons imported from Russia and Britain could turn them into a market equivalent to other regions of the world such as North Africa. Not surprisingly, countries that export conventional weapons Russia in particular - have pointed out that the economic success and obsolescence of weapons systems in Latin America offer good opportunities for the sale of new military equipment ${ }^{11}$.

Several important questions are essential to be considered when dealing with military spending budgets. In accordance to the methodology designed by Red Atlas de Seguridad y Defensa de América Latina (RESDAL), these questions are: 1) which countries spend on weapons; 2) what resources are being spent on;3) why countries decide to spend on arms (motivation); and 4) how military expenditure is funded ${ }^{12}$. Answers to these questions may give a more or less dramatic tone to the issue of arms purchases in the region. In the next sections, South American countries with large military structures - Argentina, Brazil, Chile, Colombia, Peru, and Venezuela - become the focus of attention in order to answer the first, third, and fourth questions above mentioned ${ }^{13}$.

There is disagreement among sources when it comes to recognize Venezuela as the main arms investor in South America if it is considered the relation between military expenditure/GDP. During the period 2000-2009 the country only invested $1.4 \%$ of its GDP in military expenditure. The fact is that "Venezuela has

10 Holtom, P; Bromley, M. and Wizeman, D. "International arms transference", in SIPRI Yearbook 2008. Armament, disarmament and international security. Oxford: Oxford University Press, 2008, p. 304.

11 The International Institute for Strategic Studies (IISS), "Caribbean and Latin America", Military Balance 2008, op. cit., p. 59.

12 See: Donadio, Marcela. "El presupuesto de defensa en América Latina. La importancia de la transparencia y herramientas para el monitoreo independiente" (The defense budget in Latin America. The importance of the transparency and independent monitoring tools), in: El presupuesto de la defensa en América Latina" (The defense budget in Latin America). Buenos Aires: RESDAl, 2004.

13 The amounts allocated by Bolivia, Paraguay and Uruguay to the armed forces were considerably low in the last decade; for this reason, this paper does not include them in its considerations. In the case of Ecuador, at the some point, its military expenditure will be of concern. Data shows that Ecuador spends one of the highest GDPs percentages in arms purchase in the region. 
increased dramatically its weapon imports [and] moved from $56^{\text {th }}$ position in the period 1998-2002 to the $24^{\text {th }}$ position [in the period 2003-2007], becoming the largest regional importer." ${ }^{14}$ In 2007 alone, Venezuela increased its defense budget by $78 \%$ (reaching US $\$ 887$ million), becoming the greatest spender in real terms in South America that year ${ }^{15}$. Such an amount, however, was lower than the amount of weapons imported by Chile in 2003-2007: Venezuela spent US\$ 1,417 billion against US\$2,283 billion spent by Chile. Several years of constant increase in oil prices, political will from President Chávez to improve the country's military capabilities, and presidential will to boost Venezuela's political position in the region have led the country to larger increments in its military capacities.

A remarkable fact is that in recent years there has been a considerable distance between the original military budget set and the actual yearly spending in Venezuela. This may explain why in 2006 and 2007 Venezuela ranked fourth and eighth respectively among developing countries, receiving more delivery of weapons and having signed more arms transfer agreements. ${ }^{16}$ The discrepancy between actual and expected budget spending is a consequence of legal mechanisms that allow additional allocation of resources to the military during a fiscal year. The most relevant of such mechanisms is called Paraguas Act (Ley Paraguas, in Spanish). This legal instrument, that dates back many years, allows the government to negotiate foreign loans to finance extra military spendings not always included in the initial budget, although the government has announced its intention to limit the application of the Act or even to eliminate it altogether. ${ }^{17}$

However, what kind of weapons is Venezuela buying and which countries or groups is it buying from? Between 2005 and 2007, there was a big jump in Venezuelan weapons purchases, estimated at US\$ 4 billion, most of it coming from Russia. Since 2005, Venezuela has purchased from Russia 100,000 Kalashnikov automatic rifles AK-47, 24 Sukhoi Su-30MK fighter aircrafts, 10 MI-35 combat helicopters, approximately $40 \mathrm{Mi}-17-\mathrm{V}$ multitasking transport, and $3 \mathrm{Mi}-26$ heavy transport helicopters ${ }^{18}$. In 2007, two new agreements on arms purchases were signed with Russia. According to these documents, Venezuela would receive a package of 5 Kilo-class diesel-electric submarines and possibly ground missiles

14 SIPRI Arms Transfers Data for 2007, "SIPRI data shows drop in international arms deliveries, orders remain high”, available at <http://www.sipri.org/contents/armstrad/PR_AT_data_2007.html>, accessed August 8, 2009.

15 Holtom, P; Bromley, M; Wizeman, D. "International arms transference”, in SIPRI Yearbook 2008. Armament, disarmament and international security 2008, op. cit., p. 307.

16 The International Institute for Strategic Studies (IISS), Military Balance 2008, op. cit., p. 449.

17 The International Institute for Strategic Studies (IISS), "Caribbean and Latin America", Military Balance 2008, op. cit., p. 54

18 Holtom, P.; Bromley, M. \&Wizeman, D. "International arms transference", in SIPRI Yearbook 2008. Armament, disarmament and international security 2008, op. cit., p. 306. 
and long-range S-Type Club. Venezuela also bought in the same period from China 3 three-dimensional JYl radars ${ }^{19}$.

It should be noted that the trend that puts Russia as the main supplier of weapons to Venezuela was consolidated over the comprised years being considered here. From 2003 to 2007, Russia provided 93\% of the weapons bought by Venezuela while China and Israel represent 3\% and 2\% of the total of arms imports, respectively ${ }^{20}$. In practice some of the weapons systems purchased from Russia supplement purchases made from China. For example, Venezuela probably acquired from Russia a ground-air Tor-M1 missile system. According to the country's Ministry of Defense, three Chinese radars - also purchased - will support the functions of the Russian system and even the Sukhoi aircraft fighters. In sum, Venezuela in 2007 was the third largest market to Russia's arms exports in the world (accounting for 5\%, although this percentage is well below the $45 \%$ Russia exported to China and the $22 \%$ Russia exported to India) ${ }^{21}$.

The US embargo on arms transferring to Venezuela probably had the undesirable impact for the United States of Venezuela turning to Russia as its weapons supplier. In 2006, the US State Department imposed an embargo that prevents Venezuela from importing goods and services of Defense nature. In the same year, Venezuela was certified by the US government, under Section $40 \mathrm{~A}$ of the Arms and Control Act (AECA), as a country "not fully cooperative" in the fight against terrorism. The AECA certification was renewed in 2007 and 2008. By this mechanism, Venezuela is not allowed any assistance, sale or financing by the US military. In practice, the US embargo on arms sales has led representatives of the Venezuelan armed forces to pressure the executive to look for alternative import markets. Several arms-producing countries are alert to Venezuela's air force plans to buy other types of aircraft attached to the Sukhois purchased from Russia.

Actually, the result of the US arms embargo has not been much different than expected. Combined with Venezuelan armed forces interest in buying weapons, the embargo was a strong incentive for the establishment of closer relations between Russia and Venezuela beyond ${ }^{22}$ the commercial aspect of purchase/sale of weapons. During 2008, both countries took more concrete steps in that direction. In the first half of that year, on his third visit to Russia since the beginning of his presidential term, Chávez confirmed his intention to promote strategic partnerships with Russia including energy cooperation and

19 The International Institute for Strategic Studies (IISS), "Caribbean and Latin America”, Military Balance 2008, op. cit., p. 60

20 Holtom, P.; Bromley, M. \&Wizeman, D. "International arms transference", in SIPRI Yearbook 2008. Armament, disarmament and international security 2008, op. cit., p. 306.

21 Ibid.

22 Murphy, J. “US extends embargo on Venezuela”, Janes's Defense Weekly, August 30, 2008. 
even the possibility of installing two Russian weapons factories in Venezuela ${ }^{23}$. In the subsequent years, new agreements on weapons (which would include the Su-35 and Su-39 combat aircraft; the An-74 cargo aircraft; the II-76 and Mi28 combat helicopters; and Kilo-class submarines) were discussed, even though no agreement was signed until late $2007^{24}$. During these years, Venezuela also considered acquiring 24 Sukhoi SU-30 fighters in the BM version. Additionally, Venezuela signed a US\$ 2 billion contract with Russia that includes the purchase of 4 submarines type 636, 10 Ilyushin 76MD-90 and 1 Ilyushin 78MK transport aircrafts, 2 tankers, and 10 attack Mil Mi-28NE helicopters. The Air Force has incorporated 18 training Chinese K-8 aircrafts, and the Army is in the process of finalizing the purchase of about 100 Russian T-72 and T-90 MBT, and wheeled or tracked armored troop carriers ${ }^{25}$.

This deal was followed by the announcement of the Russian Ministry of Foreign Affairs that Russian warships would hold joint exercises with Venezuela's navy, an initiative interpreted by analysts as a message to United States ${ }^{26}$. The first concrete step towards this "strategic partnership" was given in September 2008 when two Russian Tu-160 supersonic bombers arrived in Venezuela to carry out military exercises in international waters (the first exercise of military nature of a Latin American country with Russia since the end of the Cold War) ${ }^{27}$.The Russian Defense Ministry announced, though, that after undertaking the scheduled training, the aircraft would return to its home base ${ }^{28}$.

At the same time, pressures from the US government on arms-producing countries such as Spain, Brazil, and France have also had the unintended effect of inducing Russia to enter on the Venezuelan market. Pressure from the US prevented the finalization of an agreement signed by Venezuela and Spain in the second half of 2005 for the purchase of two patrol boats type 10C and a 296 $\mathrm{CN}-235$ transport aircraft. The US claimed that marketing authorization was

23 "Chávez busca aliança estratégica com a Rússia" (Chavez seeks strategic alliance with Russia), BBCBrasil, available at <http://www.bbc.co.uk/portuguese/noticias/story/2008/07/080723_chavezrussia.shtml>, accessed September 23, 2009.

24 For data on equipment acquired, see: Abdullaev, N.; Cavas, C. P. "Russia, Venezuela hint to submarine deal", Defense News, July 16, 2007.

25 Ranking do Poder Militar na América do Sul - 2009/2010 (Ranking of the Military Power in South America 2009/2010), available at <http://www.militarypower.com.br/ranking.htm>, accessed January 20, 2012.

26 Jane's Intelligence Review, "Venezuela and Russia’s message to US", available at <http://articles.janes.com/ articles/Janes-Intelligence-Review-2008/Venezuela-and-Russia-s-message-to-US.html>, accessed September $18,2010$.

27 Peru is another South American country with which Russia has a special interest in establishing military cooperation agreements. For further information, see Latin America Security \& Strategic Review, "Enhancing military cooperation", September 2007, p. 16.

28 According to military analysts, the Tu-160 is the largest military aircraft ever built and can carry up to 12 cruise missiles with conventional or nuclear warheads. These Russian planes are being used in military exercises in Venezuela, "Aviōes russos fazem exercícios militares na Venezuela" (Russian planes perform military exercises in Venezuela), available at <http://diario.iol.pt/internacional/russia-venezuela-avioes-bombardeiro-iolmilitares/989749-4073.html>, accessed September 23, 2010. 
required since both the aircraft and the patrol boats would be manufactured with technology of US origin. That same year, an agreement between the Brazilian company Embraer and the Venezuelan government for the acquisition of ALX and AMX-T Super Tucano aircrafts (a light attack training aircraft) also failed to be carried out due to the blocking position of the US for the same reason it had interfered in the transaction with Spain. ${ }^{29}$

Chile is another country that stands out in its efforts to acquire weapons of modern technology to re-equip its armed forces. In the period 2003-2007, Chile became the largest importer of (conventional) weapons in the South American region. Chile held the $36^{\text {th }}$ position in the world ranking of weapons recipient in the period 1998-2002; however, during 2003-2007, the country moved to the $12^{\text {th }}$ position (the highest position among Latin American countries ${ }^{30}$ ). Chile has also been the only Latin American country to maintain throughout the first decade of the 2000s its military spending above 3.5\% of its GDP, except for the year 2007, in which it was exceeded by Venezuela.

From 2003 to 2007, Chile's main import market for conventional arms was the European Union, accounting for $82 \%$ of the country's weapons imports, followed by the United States, accounting for $15 \%$, and Israel, with 3\% ${ }^{31}$. As some analysts suggest, choosing Western countries as its main supplier can be explained by Chile's intentions to acquire NATO standard military status and certainly the strategic partnership that the country intends to strengthen with the US in the coming decades in the political, economic, and military domains. ${ }^{32}$

In a short-term analysis, in 2007 Chile appears as the main South American importer of arms from Britain, occupying, alongside Romania, the second place in Britain's list of global arms exports ( $9 \%$ of its total exports of weapons for both countries). The dynamism of Chilean arms imports was reflected in the growth of $23 \%$ of its military budget in $2007 .{ }^{33}$

Chilean constant level of military expenditure has been made possible by two circumstances. First, the country's good economic performance in the first decade of the century. To illustrate, between 2004 and 2007, Chilean GDP grew at an average annual rate of $6.2 \%$. Second, Chilean armed forces still benefit from the Copper Law, an act that dates from the $1950 \mathrm{~s}^{34}$. In addition, during the Augusto

29 Latin America Security \& Strategic Review, "US moves against Venezuelan purchases elicits new challenges of its assumptions", January 2006, p. 1-2.

30 Holtom, P.; Bromley, M. \&Wizeman, D. “International arms transference”, in SIPRI Yearbook 2008. Armament, disarmament and international security 2008, op. cit., p. 305.

31 Ibid.

32 Ibid.

33 The International Institute for Strategic Studies (IISS), "Caribbean and Latin America”, Military Balance 2008, op. cit., p. 60-61.

34 In fact, the Ley del Cobre (Copper Law) dates from 1958, but it was modified in 1998 still under the dictatorship of Augusto Pinochet. 
Pinochet military regime, the government regulated that $10 \%$ of copper exports were to be directed to the funding of military equipment purchases and operational expenses $^{35}$. It should be noted that Chile is the world's first copper exporter and its commodity prices in the international market have experienced a steep growth over the first decade of the 2000s. ${ }^{36}$ According to some calculations, the Copper Law contributed, for many years, with an annual average of US\$ 200 million to the military budget. Due to the increase in international prices, it is estimated that the Law alone contributes with US\$ 1 billion to the military budget, leading to strong pressure from political and social sectors in Chile to revise or abolish the act. The increase of $23 \%$ in the military budget in 2007 was a preventive action in response to the existence of these social and political pressures emphasizing the need to abolish or reform the Law. These sectors advocate for military spending to be financed by the regular or general fiscal year budget ${ }^{37}$. In short, "[ $\left.t\right]$ he key to the increase in Chilean military spending is the steep rise of international copper prices in recent years. The Copper Law implemented in 1958 and later amended during the 17-year dictatorship of Gen. Augusto Pinochet stipulates that the Armed Forces are automatically granted $10 \%$ of all sales (not profits) made by the stateowned Codelco, the world's biggest copper producing company." ${ }^{38}$

In this past decade, Chile has purchased very sophisticated and technologically advanced weaponry. Among them, were 10 new US super-sophisticated combat aircraft F-16C, 18 second-hand and 18 new F16 MLU from the Netherlands ${ }^{39}$. Chile has also invested heavily in its navy, receiving 2 new Scorpene-class submarines, built by France and Spain; 2 Doorman frigates and 2 Heemskerck Van Holland frigates coming from the Netherlands; and in 2009 it was waiting for the

35 According to an estimate made by The Economist, resources allocated through the "Cooper Law" got Chile 340 tanks from Germany, 8 frigates, 2 submarines, and 28 new combat aircraft F-16. The Economist, "South America defence: speak fraternally but carry a stick", May 29, 2008. Accessed October 29, 2011.

36 Chile produces $25 \%$ of world copper. By 2005 , the mining industry will have contributed with US\$ 6.1 billion for the country, or about $25 \%$ of 2005 total tax revenue. That number may be higher today because of the international prices of copper, which rated US\$ 0.7 on average until 2003, doubled in 2005 and continued to grow in the following years. The international growth of copper prices also had a significant impact on the economies of other South American producers, particularly Peru and, to a lesser extent, Argentina and Brazil. Information on copper prices can be found at UniversiaKnowledge@Warten, "Preços do cobre aliviam cofres da América Latina" (Copper prices relieve coffers of Latin America), September 21, 2005; available at <http:// wharton.universia.net/index.cfm?fa=viewArticle\&id=1028\&language=portuguese>, accessed September 5, 2008; ÚltimoSegundo, "Com preço maior, roubo de cobre no Brasil cresce" (With higher prices, copper stealing grows in Brazil), May 6, 2008, available at <http://ultimosegundo.ig.com.br/brasil/2008/05/06/com_preco_maior_ roubo_de_cobre_no_brasil_cresce_11_em_2007_1300233.html>, accessed September 5, 2010.

37 The International Institute for Strategic Studies (IISS), "Caribbean and Latin America", Military Balance 2008, op. cit., p. 61.

38 "Chile per capita expenditure on defence, the highest of Latin america", MercoPress. South Atlantic News Agency, Tuesday, March 16, 2010, available at <http://en.mercopress.com/2010/03/16/chile-per-capitaexpenditure-on-defence-the-highest-of-latinamerica>, accessed October 24, 2011.

39 The purchase of F-16 from the United States was only made possible because the $34^{\text {th }}$ Presidential Directive, which prohibited the sale of technologically sophisticated weapons to Latin America, was reversed in the first Clinton administration, in 1997 . Before that, the $34^{\text {th }}$ Directive was only suspended once to sell a lot of F-16s to Venezuela in 1983. 
arrival of 323 -type frigates of the former Royal Navy. Chile also signed a contract with Germany to acquire 136 second-hand Leopard-2 tanks delivered in 2009. The country's missile arsenal has also been modernized: the American AIM-9M Sidewinder, AIM-120 AMRAAM, Harpoon and Sea Sparrow are being acquired. From Israel, Chile is buying the Python and Derby missiles, as well as smart bombs of various calibers. At the end of the decade, Chile also incorporated 12 A-29 Embraer Super Tucano training aircrafts and 12 new Bell 412EP helicopters to its military fleet. Recently, 3 batteries of air-defense system NASAMS were purchased, as well as about 40 8x8 armored Stryker for the Marines, 2 KC-135E aircrafts for transport and refueling planes, 14 -C maritime patrol aircraft 295MPA, 4 C-295MPA maritime patrol aircraft, and 5 Russian Mil Mi-17SP helicopters ${ }^{40}$. Chile ranked third among Latin American nations in military expenditure in 2008, spending US\$ 6 billion, following Brazil (US\$23.3 billion) and Colombia (US\$ 9.1 billion). However, on a per capita basis, Chile by far outspent both countries, since its population is (approximately) 17 million, compared to Brazil's 195 million and Colombia's 46 million $^{41}$.

In regard to Colombia, some of its politicians have raised concerns about the possibility of an arms race in South America, pointing out to a weaponry disadvantage especially in view of the recent arms purchases made by Venezuela. Thus, Colombia, following the steps of other South American countries, announced in 2008 an impressive US\$ 28 billion plan to modernize its armed forces, giving priority to upgrade their combat aircrafts Mirage and Kfir. The plan also provided for the purchase of new and modern combat aircrafts, helicopters, and armored vehicles, and an increase in army and police personnel, estimated at 36,000 people ${ }^{42}$. The first step to put the plan in practice was taken in 2007 when Colombia announced an increase in its military budget of US $\$ 3,370$ billion for the following year, the largest increase in more than 30 years ${ }^{43}$. Fighting drug trafficking and anti-insurgent paramilitary groups was the argument used by the government to justify the investment on the military.

However, Colombia's expenditures on arms purchase in terms of percentage of its GDP reveal a paradox. While the country has spent considerably little on arms purchases in the 2003-2007 period compared to its South American neighbors Chile and Venezuela, Colombia maintained the second highest military

40 "Chile comprará armas a Estados Unidos por US\$2 275 millones de dólares" (Chile will buy weapons to US by US $\$ 275$ million), chile-hoy.blogspot.com, July 8, 2009, available at <http://chile-hoy.blogspot.com/2009/07/ chile-comprara-armas-estados-unidos-por.html>, accessed January 15, 2012.

41 "Chile per capita expenditure on defence, the highest of Latin America", Merco Press. South Atlantic News Agency, Tuesday, March 16, 2010, available at <http://en.mercopress.com/2010/03/16/chile-per-capitaexpenditure-on-defence-the-highest-of-latinamerica>, accessed January 28, 2012.

42 The International Institute for Strategic Studies (IISS), "Caribbean and Latin America”, Military Balance 2008, op. cit., p. 60.

43 Holtom, P.; Bromley, M.;Wizeman, D. "International arms transference”, in SIPRI Yearbook 2008. Armament, disarmament and international security 2008, op. cit., p. 307. 
spending in the region. The numbers for expenditure on arms purchase for the period (US\$ 210 million) are far lower than Chile, Venezuela or even Brazil's acquisitions in the same period. In fact, Colombia spent 3.6\% of its GDP on military expenditure in 2000-2009, the highest percentage in Latin America. Except for Chile, which spent $3.5 \%$ of its GDP during these years, the rest of South American countries spent less than 2\%. The main suppliers of arms to Colombia during the period 2003-2008 were the United States (39\%), Spain (26.2\%), Brazil (17\%), Italy (5.2\%), and Canada (4.5\%). It is remarkable that Colombia is the only South American country that has in another Latin American country - Brazil - one of its main import markets of weapons.

To unravel the existing discrepancy between armaments purchases and a relatively high percentage of GDP spent on defense it is necessary to look at the structure of military spending funding sources. In addition to the defense budget, the Colombian government receives a war tax from cities and provinces (generating a revenue of approximately US\$ 400 million a year) complemented by a new tax, announced in 2007, expected to enhance in US\$ 43.6 billion the government revenue by $2010 .{ }^{44}$ Despite that, Colombia depends heavily on US military aid. Actually, Colombia receives the largest amount of US aid in Latin America and that aid is not accounted for in the military budget of each fiscal year. So Colombia is investing in armaments, but the source of such expenditure does not appear directly in the military budget.

The US has prioritized Colombia in military assistance programs such as the Foreign Military Financing of the State Department, the International Narcotics Control and Law Enforcement, and particularly through initiatives such as Plan Colombia and the Andean Counterdrug Strategy ${ }^{45}$. Colombia became, at the beginning of the new millennium, one of the main recipients of US military aid around the world. In the years 2003-2007, thanks to the above mentioned programs, US military aid to the country ranged from US\$ 550 million to US\$ 650 million per year. In other words, US military aid to Colombia is a contemporary version for Latin America of the "military umbrella" policy. Compared to US military assistance to any other country in the Southern Hemisphere, US military aid to Colombia is notably higher. Its impact on Colombia military structure is evident. For instance, much of the military equipment, including the modern Black Hawk helicopters, purchased by Colombia between 2000 and 2007, was only made possible due to US military assistance, particularly by means of antinarcotics programs and Plan Colombia (which, since 2000, has allocated $80 \%$ of

44 The International Institute for Strategic Studies (IISS), "Caribbean and Latin America", Military Balance 2008, op. cit., p. 60.

45 From Plan Colombia, which began in 2000, the country received US\$1.3 billion (75\% of the assistance went to the army and the police). From the Andean Anti-Drug Initiative, Colombia received an amount ranging from US\$ 465 million (in 2003) to US\$ 526 million (in 2007). Data is available at Congressional Budget Justification for Foreign Operations. (USDS Budget, 2002, 2003, 2004, 2005, 2006, and 2007). 
its US\$ 4.5 billion budget to military assistance, including purchases of military equipment). Only one lot of Black Hawks was purchased with Colombian military budget in the past decade ${ }^{46}$.

However, Colombia has not acquired sophisticated weaponry if compared to Chile and Venezuela's acquisitions. There is not many equipment today that can be compared to the Sukhoi acquired by Venezuela, or the F-16s purchased by Chile. In recent years, Colombia acquired UH-60L Black Hawk helicopters and bought a Beech B-300 aircraft converted to an air intelligence aircraft, and various units of the Super Tucano A-29 manufactured by Embraer in Brazil. The Air Force bought 13 used Kfir C10 aircrafts from Israel to rebuild its fighter force. The Colombian government agreed to participate in the design of a new KC-390 transport aircraft projected by Embraer and initially intends to acquire up to 12 units of the model ${ }^{47}$.

Any overview of the South American region in terms of total military spending or spending on arms purchases must necessarily take into account the role of Brazil due to the increased complexity of its economy, the relative relevance of its GDP in the region (around 56\%), and the greater complexity of their global and regional policy goals. Notwithstanding, in 2003-2007, Brazil reduced its international performance as an importer of conventional weapons. The country occupied the $32^{\text {nd }}$ position in a world rank in the period 1998-2002, and dropped to the $33^{\text {rd }}$ position in 2003-2007. This decrease was offset by a considerable increase in military budget (more than 33\%) in 2007, by far the most significant in a decade. This explains why Brazil, which occupied the $14^{\text {th }}$ position in 2006 among countries with increased military spending, and rose to the $12^{\text {th }}$ position in $2007^{48}$. Brazil occupied, in 2010 , the $30^{\text {th }}$ position in the world ranking of weapons importers. "However, the elect Brazilian President Dilma Rousseff has delayed awarding a US\$ 2 billion contract for advanced combat aircraft and a US\$ 6 billion contract for frigates and offshore patrol vessels (OPVs)." ${ }^{\prime 9}$

However, attention must be paid to the fact that Brazilian military spending of nearly US\$ 70 billion in the period 2003-2007 is diluted by the size of its economy: for 2007, the country's GDP was around US\$ 1.5 trillion (or R \$ 2.5 trillion $^{50}$ ). Taking into account the relation military spending/GDP, Brazil spends little on defense (1.6\% of its GDP) when compared to Colombia $(3.5 \%)$ or Chile

46 SIPRI Arms Transfers Database, available at <http://www.sipri.org/contents/armstrad/at_db.html >, accessed January 24, 2012.

47 Military Power Review, "Ranking do Poder Militar na América do Sul - 2009/2010" (Ranking of the Military Power - 2009/2010), available at <http://www.militarypower.com.br/ranking.htm>, accessed November 21, 2011.

48 Stepanova, Ekaterina. "Trends in armed conflicts". SIPRI Yearbook 2008, p. 12.

49 Holtom, Paul et al. "Trends in international transfers, 2010". SIPRI Fact Sheet. SIPRI, 2001, p. 5, available at <http://books.sipri.org/product_info?c_product_id=421\#>, accessed March 18, 2012.

50 IBGE (Instituto Brasileiro de Geografia e Estatísticas), "Brasil em sínteses", available at <http://www.ibge. gov.br/brasil_em_sintese/default.htm>, accessed September 20, 2011. 
(3.5\%), and only slightly more than Argentina (0.96\%) and Peru (1.3\%). In the period 2003-2007, on average, $1.5 \%$ of Brazil's GDP were directed to military expenditure. It should also be taken into account, however, that in spite of defense budget growing an average $15 \%$ between 2004 and 2007, only $4 \%$ of the budget can be allocated to new equipment acquisitions and armament upgrade. The rest of the budget is spent primarily on military personnel, including expenses with pensions. Therefore, the actual spending in equipment and weapons upgrade in the period 2003-2007 was of US\$ 818 million, lower than Chile's and Venezuela's investments.

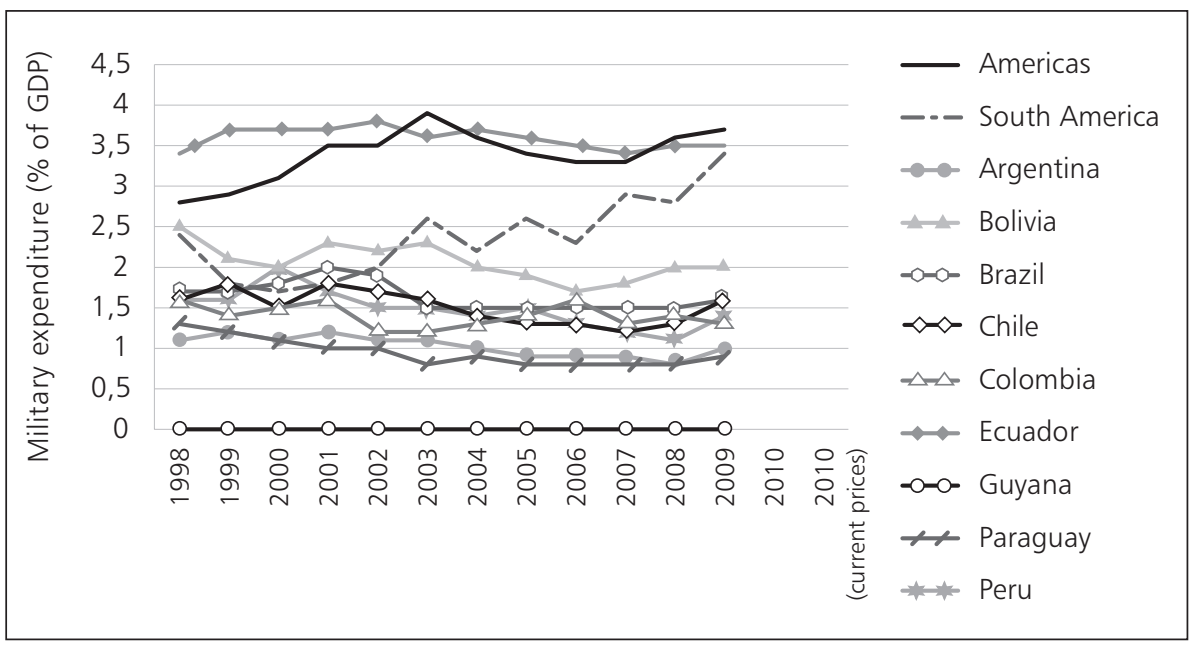

Figure 1. Military expenditure by country as percentage of GDP from 1998 to 2009. Source: according to SIPRI database (2011).

Regarding the institutional aspect, Brazil does not have any extra-budget mechanisms like Chile, Colombia and Venezuela. The military budget is based on the Budget Act (Lei Orçamentária, in Portuguese) approved by the National Congress annually. The Budget Act, however, allows regular military budget to be complemented throughout the year. For 2010, R\$ 1.5 billion (US\$ 853 million) from the Budget Act was allocated to the Ministry of Defense to improve the existent airspace control system and to develop airport infrastructure. ${ }^{51}$ Along with many other countries in the region, Brazil has in recent years started on a program to modernize and upgrade its armed forces. The 2008 National Defense Strategy announced plans to boost Brazil's military capabilities and to invigorate its domestic arms industry through a series of acquisitions which includes significant volumes

51 Freeman, Sam P. et al. "Military expenditure". SIPRI Yearbook 2011. Oxford: Oxford University Press, 2011 , p. 71. 
of technology transfer. In 2010, in a first step towards implementing the National Defense Strategy, the National Congress approved a project to restructure the armed forces that foresees the creation of a Joint General Staff to work under the authority of the Ministry of Defense. In this same direction, a draft proposal to Brazil's first Defense White Paper was issued in 2011. According to this document, every four years the government will have to submit to the National Congress detailed information on its defense policies and strategies along with plans to a continued modernization of the armed forces ${ }^{52}$.

The Brazilian Navy plans to purchase at least 33 modern ships by 2025 in order to make patrolling of maritime boundaries more effective. However, some projects, such as the development of the Brazilian nuclear submarine, have been delayed to meet more pressing demands such as the modernization of existing ships. Thus, in 2006 a further postponement of the project (which had its first impulse almost 30 years ago) was announced and the Navy stated its intentions to give priority to the modernization of the existing Type-209 submarine and the construction of a submarine (Type 214) using German technology. In any case, the nuclear submarine project received a strong stimulus when the Brazilian government announced in mid-2007 its plan to invest US\$ 1 billion over an eightyear period in buying German and/or French technology for the construction of a reactor, which is linked up to the submarine project.

The Brazilian Air Force has experienced lack of resources just as the Navy. For instance, the Ministry of Defense produced an ambitious project in 2002 called the FX Project, reissued in 2007 . The project proposes to buy initially 36 modern aircraft fighters, reaching more than 100 by 2020, to replace the outdated Mirage, the AMX attack and tactical F-5BR that Brazil maintains ${ }^{53}$. At the end of the decade, the Brazilian Air Force received the first batch of the three acquired Russian attack Mil Mi-35M helicopters. The Air Force has also ordered 4 more units of the UH-60 Black Hawk helicopter, plus 8 units of CASA C-295 transport aircrafts, and signed a contract with Embraer to purchase 28 units of the new KC-390 transport aircraft ${ }^{54}$.

In October 2008, the Air Force announced the three finalists companies all of which are Western ${ }^{55}$ - competing to provide the new generation of combat aircrafts to the Brazilian military. A contract for their acquisition would be signed in

\section{Ibid}

53 Military Power Review, "Ranking do Poder Militar na América do Sul - 2005/2006" (Ranking of the Military Power in South America - 2005/2006), available at <http://www.militarypower.com.br/ranking.htm>, accessed November 21, 2011.

54 Military Power Review, "Ranking do Poder Militar na América do Sul - 2009/2010" (Ranking of Military Power in South America - 2009/2010), op. cit., accessed November 21, 2011.

55 These companies are: the Swedish Saab Gripen, the French Dassault Rafale and the US Boeing F/A-18E/F Super Hornet. Stratafor "Brazil: Momentum builds for Defense Reform", October 2, 2008, available at <http:// www.stratfor.com/analysis>, accessed October 4, 2011. 
2009 and delivered in 2014. Thanks to that, the Ministry of Defense would see its budget increased for a long time. For that, an important decision should have been taken in 2009, when the National Budget Act would provide US\$ 50.2 billion for the Defense. Of this total, US\$10.9 billion is to be allocated for direct investment in the Army, Navy and the Air Force ${ }^{56}$.

From 2003 to 2007, Brazil bought most part of its weaponry from the European Union (64\%), followed by the United States (17\%) and Canada $(7 \%)^{57}$. Some analysis suggests that it is not by chance that Brazil, like Chile, has given preference to Western suppliers, with special interest in NATO members, rather than Russia or China. That would be a deliberate selection, following a rationality involving "strategic choice": its emergence as a regional power in the next decade does not seem to predict a relationship of rivalry with the West, but on the contrary, a partnership for regional security plans ${ }^{58}$. It should be noted, however, that due to domestic political conditions and financial difficulties, Brazil has bought second-hand weapons. Thus the country bought 12 used Mirage 2000C from France, which were delivered into three batches of 4 aircrafts in 2006, 2007 and 2008. From Spain, the country bought 12 new C-295M transport aircrafts, which were delivered by the end of 2008, and 2 Lockheed P-3 Orion aircrafts set up for maritime surveillance. Brazil also acquired 9 F-5E aircrafts from Saudi Arabia and has a project to purchase 240 Leopard 1A5 tanks to the Army (having already received the first two lots ${ }^{59}$. From the Brazilian private company Embraer, the government has purchased 50 Super Tucano EBM-314 training and combat aircrafts and, to cater to the Army, signed a contract to purchase 2,044 units of armored wheeled transport VBTP, now dubbed Guarani, in different versions.

There are two other South American countries that have important regional armed forces in the region and have shown willingness to modernize its military structures in the coming years: Peru and Argentina. The case of Peru, whose former president Alan Garcia announced in 2007 plans to invest over US\$ 1 billion in modernizing the armed forces ${ }^{60}$, is of particular importance since, following Brazil, Peru is the country that has numerically the largest armed forces in South America ${ }^{61}$.

56 Alencastro, Catarina \& Jungblu, Cristiane. "Novo plano de defesa nacional prevê serviço militar obrigatório para mulheres" (New plan of national defense provides compulsory military service for women), O Globo/ Reuters, available at <http://bf2brasil.com/forum/showthread.php?p=676863>, accessed September 22, 2011.

57 Holtom, P.; Bromley, M.; Wizeman, D. "International arms transference”, SIPRI Yearbook 2008. Armament, disarmament and international security 2008, op. cit.

58 Stratafor, "Brazil: Momentum builds for Defense Reform", October 2, 2008 (translated by authors), available at <http://www.stratfor.com/analysis>, accessed May 10, 2011.

59 Military Power Review, "Ranking do Poder Militar na América do Sul -2009/2010" (Ranking of the Military Power in South America - 2009/2010), available at <http://www.militarypower.com.br/ranking.htm>, op. cit., accessed December 1, 2011.

60 Military Balance 2008, "Caribbean and Latin America", op. cit., p. 61; see also: Cruz, Tantalean C. "Peru’s updated plan shifts focus", Janes's Defense Weekly, October 10, 2007, p. 31.

61 Military Power Review, "Ranking do Poder Militar na América do Sul - 2005/2006" (Ranking of the Military Power in South America - 2005/2006), op. cit., accessed December 12, 2011. 
Peru's military spending in the period 2000-2009 remained almost constant, on an average $1.4 \%$ of its GDP, and its military budget virtually coincided the original expected expenditures with its real one. Figures show that Peru is one of South American countries with lower spending numbers on arms imports. That can be explained by two situations: the many severe economic crises that affected Peru in the past decade, and the decision to buy a small number of sophisticated weaponry, at least during the period 2003-2007. The country acquired in 2007 two used Lupo class frigates and expects two more from the Italian Navy. Up to now, Peru has no (public) plans to acquire sophisticated military weapons in the short term. Thus, as only $30 \%$ of its combat aircrafts are in operational conditions $s^{62}$, priority falls on maintenance and modernization of weaponry bought in the 1980s and 1990s, especially the IKL 209/1200 submarines and the French Mirage 2000. Peru also signed with Russian companies an agreement to maintain operational their Mig-29 and Mi-17 fighters, and their An-32 helicopters ${ }^{63}$. Peru acquired two Fokker $60 \mathrm{MPA}$ maritime patrol aircrafts from the Netherlands inventory in order to strengthen fight against the Shining Path guerrillas. The government also ordered 8 new Russian attack helicopters Mil Mi-35P, and 6 Russian Mil Mi-17SP for transportation. This probably means that Peru will continue to make efforts for keeping markets that in the past have been suppliers of its advanced weaponry, especially France and Russia. Peru, contrary to the case of Brazil, Chile and Venezuela, is not facing its imports market as "strategic choices," but as a commercial safe choice.

However, following the trend of several South American countries (especially Chile and Venezuel ${ }^{64}$ ), Peru uses its natural resources sales as a source of military funding. In its efforts to modernize the armed forces, Peru created a defense fund in 2005 subsidized by income derived from the exploitation of hydrocarbons ${ }^{65}$ (especially from gas). Thus, given the excellent oil prices in the international market, part of the designed modernization program of the Peruvian armed forces is expected to be funded during the second term of president Alan Garcia (2007-2011). Income from armed forces properties will provide complementary funding. ${ }^{66}$

62 The International Institute for Strategic Studies (IISS), "Caribbean and Latin America”, Military Balance 2008, op. cit.

63 Military Power Review, "Ranking do Poder Militar na América do Sul - 2005/2006(Ranking of the Military Power in South America - 2005/2006), op. cit., accessed September 18, 2011.

64 Bolivia is another country that has announced its intentions to allocate natural resource revenues from gas sale in military spending. In 2007 an official proposal to allocate $2 \%$ to $3 \%$ of such an income to modernize the armed forces was made. (Buranauskas, T. "Bolivian military to get additional funding to finance revitalization", available at $<$ http://emarketalerts.forecast $1 . c o m /$ mic/eabstract.cfm?recno $=130472>$.

65 SIPRI, "Military expenditure of Peru", available at <http://milexdata.sipri.org/result.php4>, accessed November 18, 2011.

66 The International Institute for Strategic Studies (IISS), "Caribbean and Latin America", Military Balance 2008, op. cit., p. 61. 
Argentina, on the other hand, is a curious case. No doubt the country represents one of the most vigorous cases of political and economic development in South American region at present. However, even though during Nestor Kirchner's administration (2003-2007) macroeconomic indices suggested an average growth of over $8 \%$ a year, Argentina presents low levels of military expenditure (in 2008, it reached a floor of $0.8 \%$ of the GDP, against $1.1 \%$ in 2000) and has not stated any future plans for major investments in military equipment ${ }^{67}$. Thus, Argentina experienced a decrease of $1.6 \%$ in its military budget in 2004 , losing the position of fourth biggest military spender in the region that it occupied then. Similar rates of decrease during the next following two years (2005 and 2006) made Argentina lose further positions in the regional military ranking, especially to Peru and Colombia $^{68}$. For the period 2000-2009, in terms of military spending/GDP, Argentina's military budget, compared to other South America countries, was only greater than Paraguay, which allocated an average $0.9 \%$ of its GDP. It was lower even than Uruguay, who spent an average $1.5 \%$ of GDP in the same period. Of course, these figures cannot lose sight that, in absolute terms, Argentina's budget is several times higher than that of Paraguay and Uruguay. One example that shows how the political and financial crisis during the early first decade of the new century negatively affected the purchase of advanced weaponry in Argentina is the impressive fact that the last purchase Argentina did until 2008 was a Bell-212/ $\mathrm{UH}-1 \mathrm{~N}$ helicopter in $2000^{69}$.

Clearly, besides the economic crises at the beginning of the decade, the memory of the violent years of military dictatorship in the country also accounts as an important factor in explaining why civil governments in Argentina invest so little in military modernization. Thus, from 2003 to 2007, Argentina acquired AIM-9M Sidewinder missiles, bought second-hand units of Mirage 2000C, and with its own technology built a Corvette, the Meko $140 .{ }^{70}$ Under the government of Cristina Kirchner, Argentina undertook the modernization of UH-1 helicopters and light attack IA-58 Pucara aircrafts, extending their operational life for at least another ten years. Two units of Russian helicopter Mil Mi-17V were acquired to undertake operations in Antarctica. ${ }^{71}$

67 CadahQueija, Lucas. "Relatório Final de Iniciação Científica: Política de defesa e investimentos militares na América do Sul: Brasil, Argentina, Chile e Venezuela." (Final Report of the Scientific Initiation: Defense policy and military investments in South America: Brazil, Argentina, Chile and Venezuela), Universidade de São Paulo/ DCP, 2008.

68 Military Power Review, "Ranking do Poder Militar na América do Sul - 2009/2010" (Ranking of the Military Power in South America - 2009/2010), op. cit., accessed January 26, 2012.

69 See: SIPRI Arms Transfers Database, available at <http://www.sipri.org/contents/armstrad/at_db.html>, accessed February 22, 2012.

70 Military Power Review, "Ranking do Poder Militar na América do Sul - 2005/2006" (Ranking of the Military Power in South America - 2005/2006), op. cit., accessed August 26, 2009.

71 Military Power Review, "Ranking do Poder Militar na América do Sul - 2009/2010" (Ranking of the Military Power in South America - 2009/2010), op. cit., accessed January 26, 2012. 
In mid-2007, though, the government announced a more comprehensive modernization program of its armed forces ${ }^{72}$, including purchases from France (traditional supplier of Argentina in the past), Ukraine, and Russia. From France, Argentina intends to acquire second-hand Mirage $2000 \mathrm{C} / \mathrm{Ds}$ and Mica and Exocet missiles; from Ukraine, an An-70/72 transport aircraft to replace the old C-130. These purchases were, however, by the end of the first decade, still a plan, and it seems that Cristina Kirchner's government will further postpone the modernization project of Argentinean military.

In short, Chile was the largest import of conventional weapons in 2006-2010 and the $12^{\text {th }}$ largest in the world, and the total volume of transfers to the region increased by nearly $150 \%$. Venezuela's arms imports are likely to remain high in the next years. Other states in South America, including Argentina, Colombia, and Peru are engaged in more modest efforts. Orders for Brazil arms imports increased by $436 \%$ between the periods 2001-2005 and 2006-2010, driven in large part by licensed production deals with France for 4 Scorpene submarines, 1 SBNR and 50 EC-725 helicopters ${ }^{73}$.

\section{Conclusion: trends to the next decade}

A new report of SIPRI, published in 2011, states that weapons imports to South America during the 2005-2006 period rose by 150\% compared to the 2000-2004 period. SIPRI attributes this strong rise to high prices of commodities, such as soybean, oil, and cooper. The three South American countries that have bought more weapons during the first decade of the new millennium were Chile $\left(13^{\text {th }}\right.$ in the world ranking), Venezuela $\left(17^{\text {th }}\right.$ in the world ranking), and Brazil $\left(30^{\text {th }}\right.$ in the global ranking $)^{74}$.

However, despite economic factors being an important parameter to explain the weapons imports, the information and data presented and analyzed in this paper suggest several more complex trends about modernization of the armed forces and South American military build-up in the first decade of the 2000s:

Almost all South American countries announced large military plans to modernize and reform its armed forces, necessarily implying an increase in spending on the medium-term. That suggests military spending should increase over the next ten years ${ }^{75}$.

72 Barragan, J. M.; Higuera, J. "Buenos Aires announces forces funding boost” Janes's Defense Weekly, October 31, 2007.

73 Holtom, Paul et al. "Trends in international transfers, 2010". SIPRI Fact Sheet, op. cit., p. 5-6.

74 Information quoted from "Chile per capita expenditure on defence, the highest of Latin america", MercoPress. South Atlantic News Agency, Tuesday, March 16, 2010, available at <http://en.mercopress.com/2010/03/16/ chile-per-capita-expenditure-on-defence-the-highest-of-latinamerica>, accessed January 24, 2012.

75 This conclusion coincides with the argument of Hodge, Natham. "FIDAE 2008 highlights: continuing upsurge in Latin American procurement”, Jane’s Defence Weekly, May 3, 2012. 
Almost all South American countries have initiated a recapitalization of its obsolete military stockpile, dated in its majority to the 1950s to 1960s, being the most modern ones from the 1980s. This recapitalization aims solely to update and replace old military equipment. Apart from the cases of Chile and Venezuela, other South American countries intend to upgrade their equipment, and the purchase of second-hand transportation units and weaponry seems to be the preferred choice due to financial constraints. Spending in 2010 was $42 \%$ higher in South America than in 2002, and military spending increased significantly in 7 of the 10 South American countries, including countries relatively less influent in regional affairs like Paraguay (16\%) and Peru (16\%), with low military expenditure through the first decade of the millennium ${ }^{76}$.

South American countries with major military capability (specifically Chile, Colombia, Peru and Venezuela) benefit from additional mechanisms to increase their military budget beyond the legislative stipulation for defense expenditures (the Copper Law in Chile, the "Umbrella Law" in Colombia, etc.). Therefore, the original military budget in each fiscal year rarely coincides with the real military spending.

There is great asymmetry in the level of arms purchases among South American countries: Chile and Venezuela do not represent the spending pattern of the region. Beyond that, almost all military institutions suffer from financial constraints, hence the option for purchasing second-hand equipment to be credited as the most viable way of funding their modernization projects.

There is a strong tendency among the Andean countries (plus Chile) to use their export commodities (oil, gas, and copper) to finance military spending and support its plans to modernize the Armed Forces and their military equipment.

South American weaponry market is no longer predominated by the United States. EU countries such as Great Britain, Spain, Germany, and France configure the main import markets for weapons. Russia has an aggressive policy of weapons exportation towards the region but still focus most of its initiatives to countries such as Venezuela.

Received March 18, 2012

Accepted June 28, 2012

\section{Abstract}

In recent years, with some frequency it is heard that Latin America, especially South America, is witnessing the rise of an arms race. Frequent reports in the press and strong statements made by politicians in the region have fueled this fear. At the same time, scholars have also reached

76 Freeman, Sam P. et al. "Military expenditure", SIPRI Yearbook 2011, op. cit., p. 184. 
to this conclusion, as pointed out by Malamud and Garcia: "The famous arms race in Latin America, led by Venezuela, is no longer just talk."

Keywords: South America; military purchase; military spending; trends.

\section{Resumo}

Recentemente, com certa frequência, tem-se ouvido que a América Latina, em especial a América do Sul, tem testemunhado o surgimento de uma corrida armamentista. Relatos frequentes à imprensa e fortes declarações feitas por políticos da região têm alimentado esse receio. Ao mesmo tempo, estudiosos também têm chegado à mesma conclusão, tal como salientaram Malamud e Garcia: "A famosa corrida armamentista na América Latina, liderada pela Venezuela, já não é apenas discurso."

Palavras-chave: América do Sul; aquisições militares; gastos militares; tendências. 